\title{
GERMAN LANGUAGE COMPOSITES IN HERMAN HESSE'S NOVEL SIDDHARTA AND THEIR CORRESPONDENCES IN THE INDONESIAN LANGUAGE
}

\author{
Sulis Triyono \\ Fakultas Bahasa dan Seni, Universitas Negeri Yogyakarta \\ email: sulis@uny.ac.id
}

\begin{abstract}
This study aims to describe forms and meanings of German language composites and their correspondences in the Indonesian language. This was a qualitative descriptive study. The data were in the form of composites in German sentences in Herman Hesse's novel Siddharta and its Indonesian translation by Hedy Holzwarth. The data were collected through the reading and writing technique. They were analyzed by the comparison and distribution techniques. The results of the study are as follows. First, there are 268 forms of composites, consisting of the Nullkonfix form, comprising a combination of noun+noun with a total of 161, a combination of adjective+noun with a total of 5, Konfixbeteiligung /-s/ (22 words), Konfixbeteiligung /-n/ (49 words), Konfixbeteiligung /-en/ (6 words), Konfixbeteiligung /-er/ (17 words), and Konfixbeteiligung /-r/ (5 words). Second, German language composites are formed through the derivational and inflectional processes. A word formation functions as an attribute in a composite. In the Indonesian language, it is formed through an affixation process. Therefore, it can be concluded that German and Indonesian language composites have similar processes and meaning correspondences.
\end{abstract}

Keywords: German and Indonesian language composites, correspondences

\section{KOMPOSIT BAHASA JERMAN DALAM NOVEL SIDDHARTA KARYA HERMAN HESSE DAN PADANANNYA DALAM BAHASA INDONESIA}

\begin{abstract}
Abstrak
Penelitian ini bertujuan untuk mendeskripsikan bentuk, makna,dan padanan komposita bahasa Jerman ke dalam bahasa Indonesia. Penelitian ini adalah penelitian dekriptif kualitatif. Data berupa bentuk komposita dalam kalimat bahasa Jerman berasal dari buku roman Siddharta karya Herman Hesse dan karya terjemahan bahasa Indonesia oleh Hedy Holzwarth. Pengumpulan data menggunakan teknik simak dan catat. Analisis data menggunakan padan dan agih. Hasil penelitian sebagai berikut. Pertama, bentuk komposita berjumlah 268 buah, meliputi bentuk Nullkonfix berupa penggabungan nomina+nomina sebanyak 161 buah, penggabungan adjektiva+nomina sebanyak 5 buah, Konfixbeteiligung/-s/ (22 kata), Konfixbeteiligung /-n/ (49 kata), Konfixbeteiligung/-en/ (6 kata), Konfixbeteiligung/-er/ (17 kata), dan Konfixbeteiligung /-r/ (5 kata). Kedua, komposita bahasa Jerman dibentuk berdasarkan proses derivasi dan infleksi. Konstruksi kata ada yang berfungsi sebagai atribut dalam komposita. Adapun dalam bahasa Indonesia dibentuk berdasarkan proses afiksasi. Dengan demikian, dapat disimpulkan bahwa komposita bahasa Jerman dan bahasa Indonesia memiliki kesamaan proses dan padanan makna.
\end{abstract}

Kata kunci: komposita bahasa Jerman dan Indonesia, padanan 


\section{INTRODUCTION}

German language composites, also called as Zusammensetzung, can be defined as a 'kata majemuk' in Indonesian. Language composites are the combination of two or more words which become one word having new meaning. The result of the combination is then called as 'kata majemuk' (compounds) in Indonesian. The structure of the composites can be acombination of noun+noun, adjective+ noun, adverb+noun. Therefore, it can be said that the combination can be free morpheme+free morpheme or bound morpheme+free morpheme.

German composites consist of two elements: the first one is Bestimmungswort 'determiners' i.e. the bound morphemes and the second one is Grundwort 'primary word' i.e. the core element. Purpose wordis the determinative element since it determines meaning in the composites, for instance the word das Haus 'house' and the word die Tür'door' become the 'compound' composite of Haustür'house door'. The compounddie Haustür'house door' possesses article die because the word die Tür is a determiner. As for the word das Haus(house), it is the Bestimmungswort which functions as the descriptor for the attached syllables. This is in line with Duden (2014) who states that the word Türin the word Haustür is the determiner, while the word Hausin the word Haustür is the primary word.

Compound words in Indonesian often use the terms of 'Diterangkan' and 'Menerangkan' or are commonly called as the Law of DM, that is to say in the compound 'house door', the descriptor is the word 'house', while the described one is the word 'door'. In spite of German, the compound 'house door' will be said as Haustür. The word Haus is the describing primary wordwhile the word Türis the one being described. So, it can be concluded that the German 'compound' language composites follow the Law of MD, while the Indonesian 'compound' language composites follow the Law of DM.

Combinations of two or more syllables can cause the emergence of akzent (intonation stresses) in the language composites. These can be grouped in three types, as in the following examples:

1. Welt'hungershilfe (w $\backslash 1 \mathrm{t}$ 'hŠKXXr) 'world hunger aid'

2. 'Frauenparkplatz ('fraXnparkplatz) 'ladies parking area'

3. Weihnachts'plätzchen(waihnachts'plaet zchXn) 'Christmas coockies

Based on these examples, it is stated that the first group has intonation construction of $(a+(b+c))$, in which $(a)$ is the word Welt, which gets low intonation, while $(b+c)$ is the word 'Hungershilfe', which gets high intonation. Example (2) has the intonation construction of $((a)+b+c)$, in which $(a)$ is the word Frauen which has high intonation whereas $(b+c)$ is the next syllables which do not get high intonation. As for example (3), it has intonation construction of $(a+b+(c))$, in which (c) is the word plätzchen which has high intonation stress, while the syllables of the wordWeihnachtsdo not get any intonation stress. The third syllable is located in the last position whereas in $(a+b)$ i.e. the word Weihnachts, it is located in the first and the second syllable which do not get high intonation stress.

In contrast to language composites having only two syllables, the intonation stress is always in the first syllable. This is as proposed by Engel (1991 : 519) who states that das Bestimmungswort des Kompositumsträgtimmer den Hauptakzen: Gártengerät, Ápfelmost, Kérzenschimmer (determinative elements as the bound morpheme in compounds are always in the first syllable, as in gardening tools, pureed apples, and candlelight.

In German, as proposed by Duden (2005: 712), the term Kompositionsfugerefers to an added composition in the form of Konfixbeteiligung, i.e. vocal or consonant in compounds. This addition is done by

German Composites in Herman Hesse's Novel Siddharta and Their Correspondences in Indonesia 
inserting vocal or consonant element in the language composite. This shows how complex German language composite formation can be. Besides creating changes in the akzent(the intonation stress) on the first syllable, there might be intonation stress change on the last syllable. This change is due to the existence of composite formation. On the other hand, there are differences in the infix in the form of vocal and consonant used in the process of a language composite formation.

In German, language composite is one of many which is commonly used in sentences because it has such important functions. In order to form composites, several ways can be done, namely: (1) the combination of two free morphemes in the form of noun + noun refers to the noun composite, (2) the combination of two free morphemes in the form of adjective + noun refers to the adjective composite, (3) the combination of two free morphemes in the form of adverb + noun refers to the adverb composite, (4) the combination of two free morphemes in the form of verbs refers to the verb composite, and (5) derivation. As a result, the composite formation from the combination of several free morphemes leads to the emergence of new semanticfeatures.

Based on the composite formation, German language learners who are also foreign speakers find it difficult to learn. It is as stated by Engel (1991: 520) that semantic typology in the composite will be clearly shown in a sentence, if a part of its element composition corresponds with the case. In this case, it is not easy to understand a composite unless the native speaker or foreign speakers who are experts in the language. Problem emerges when learners learn the composites for the first time. For that reason, adequateexplanations on the German language composite formation are needed. The construction of the composite can be seen as follows:
einBusfahreristeiner, der einen Bus fährt 'a bus driver is someone who drives a bus'

Viewed from its roles in a sentence, a German composite can be said as having several semantic features. These features have meanings as agentis (agent), instrumenti (instrument), and aktionis (action) (Engel, 1991: 522). As for language composites having the agentis meaning, it is a language composite bringing out an action in its rightful semantic features (das Bestimmungswortbezeichnet das von der HandlungBetroffene), for example in the composite word Bienenzüchter (bee keeper) and Zeitungsleser (newspaper reader). A composite having instrumenti meaning is a language composite which has meaning of a property caused by actions (das Bestimmungswortnennteinedurch die Handlungbewirkte Eingenschaft), as in Gesundsbeter'Healthy' and Muntermacher 'Cooper'. A composite having aktionis meaning is a language composite which has meanings that there are changes in behavior or actions (das Bestimmungswortmodifiziert die Handlung), as in composite Naßkopierer (wet photocopier) and Schnelldrucker (fast printer).

The focus of this study is problems in German composite formation in becoming compound words having new meanings. The novel entitled Siddhartaby Herman Hesse was not chosen without reasons. It should be noted that Herman Hesse was a well-known poet of Swiss-German descent who had traveled to India that inspired him to write a literary piece entitled Siddharta. He was a German and was interested in literature. His works became references for worldwide writers until today. In 1946 he won the Nobel Prize in literature (from the Swedish government).

German composites possess various lexical forms. This is due to the formation process which can be done in several 
ways, as stated by Engel (2001: 511) that compounds are derived from the combination of the existing words. The compound formation is done by adding other elements in bound morphemes or by adding the core morpheme'. Furthermore, Engel (2001: 519) states that noun composites consist of two components: the first one as the root, and the second one as the bound element as a result of inflections, for example Dichterkomponist 'Poet Composer'. The second component does not affect the genus and flexes of a composite.

Engel (2001:519) states that composites have meaning relationships which are not translated word per word, but the whole context in the composite. If someone does not master German well, then peculiarities will emerge in the process of forming new composites.

For that reason, well comprehension is needed, so that there will not be any rule deviation in forming new composites. The formation affects the intonation and semantic features. This is in line with Eisenberg (2004) who states that there are three processes of language composite formation, it can be understood from the constructing form, namely (1) having the form, in which the second part gets high intonation stress, while (c) does not get any akzent; (2) having the form, in which there is no high intonation stress to this part whereas other parts have akzent; (3) having the form of $((a b) c)$, where the first part, i.e. ( $(\mathrm{a} b)$ always gets tone stress, whilst part (c) does not get any akzent'.

Duden (2009: 50) proposes that in language composites only consisting of two syllables, the first syllable gets high tone stress if pronounced, while the second one does not. Substantive composites do not depend on the form complexity level individually, but on the unchangeable form not only in the syllable that becomes the core morpheme, but also in the syllable that becomes the bound morpheme. Furthermore, Duden
(2009: 712) states that the weakness in language composites formation is in the konfix addition. It can be viewed from the formation which conveys three methods, namely: (1) not changing the form and its basic elements, (2) without additions, unless in vocal /e/ in the first syllable of some specific composites, it is eliminated, such as in the word Schulbuch (school book), (3) adding consonant /s/ as in Tagesreise(one day trip).

Duden (2014) suggests that bound morphemes are located in the first syllable of a language composite, while the core morpheme is located in thelast syllable, as in the word Haus which is located in front of the word Tür so that they become Haustür. This shows how important the location of syllablesin the composites is becauseit can affect meaning.

Based on the above problems, an indepth study on the form and meaning of German language composites in the novel Siddhartaand their equivalence in Indonesian were required. It is expected that students will understand forms and meanings of German language composites and their Indonesian equivalence through this study. Therefore, problems are formulated as follow: (1) how are forms and meanings of the German composites in Siddhartanovel by Herman Hesse?(2) their Indonesian equivalence in Siddhartanovel by Herman Hesse?

This study is aimed at describing: (1) forms and meanings of German composites in Siddhartanovel by Herman Hesse, and (2) German composites and their Indonesian equivalence in Siddhartanovel by Herman Hesse.

\section{METHOD}

The object for the data of this study is all forms of language composites in all German sentences in the Siddhartanovel and all sentences in the Indonesiantranslated work. The subject is German and Indonesian composites. 
The data resource in this study is all German language composites categorized as newly formed only noun as the result of the combination of two or more words in German and their composite equivalence in Indonesian.

The data were collected from Siddharta novel in German and in the Indonesiantranslated work as follows.

1. Siddharta Novel. Eineindische Dichtung von Herman Hesse. Erster Teil. 1922. Published by Suhrkamp Verlag in German, Lindenstrasse 29 - 35, SuhrkampHaus 60325, Frankfurt am Main. Book thickness 86 pages.

2. Siddharta Novel by Herman Hesse. A Nobel Prize in Literature Winner. This book is translated by Hedy Holzwarth and studied by Goethe Institut. Bentang Pustaka Press, Indonesia. ISBN: 9793062223 . Book thickness 236 pages.

The data in this study are collected by employing the read and noted technique (Sudaryanto, 1996). This technique is done by reading the whole content of Siddhartanovel either in the German or Indonesian version. Then, a thorough recording of all the corpus data in the form of 'compound' composites are done. The record is done in the data card to ease the corpus data categorization. It is needed for the following analysis materials in order to find the meaning equivalence between German and Indonesian (Wray, 2003: 153).

The data were analyzed using 2 methods, namely the matching and distribution method (Sudaryanto, 1998). The matching method employed is the referential sorting technique. References in the form German and Indonesian language composite are used in this technique. The distribution method uses the element division and marker reading technique. The element division technique is applied to find out the form of German and Indonesian language composites.
The reading technique is applied to find out to determine the form and meaning of German language composites in the novel Siddharta and their Indonesian equivalence. The collected data were then tested for validation by checking and rechecking with the help of a native speaker who was also the guest lecturer from Deutsche AkademischeAustauschdienst (German Academic Exchange Service) in the German Education Study Program in the Faculty of Languages and Arts, Yogyakarta State University. The validation was for validating the collected corpus.

Furthermore, verification was done in the data from the study by a colleague of the Linguistic cluster to find out whether or not the data were reliable. Moreover, verification was done in the Research Proposal Seminar forum (Research Instrument Seminar) which was done in May 6, 2015 by the Research Advisory board of the Faculty of Languages and Arts, Yogyakarta State University.

Besides, the result of the study was also validated in the Research Result Seminar forum held by the Research Advisory board of the Faculty of Languages and Arts, Yogyakarta State University in October 8, 2015.

\section{RESULTS \& DISCUSSION}

The findings showed that the form of composites in the novel Siddharta EineindischeDichtungby Herman Hesse appeared in 268 forms. Based on these forms, it can be specified that composites with formation processes without konfix can be called as Zero konfix, i.e. there are 161 combined form between noun + noun and 5 composites of combined form between adjective + noun.Composites in the form of Konfix Participation/-s/ consists of 22 compound words, $K P /-n /$ consists of 49 compound words, $K P$ /-en/ consists of 6 compound words, KP /-er/ consists of 17 compound words, and $K P$ $/-r /$ consists of 5 compound words. 
Apart from that, thereare compounding forms by adding prefixes before a word: Präfix /Ge-/ for 1 word and Präfix/Ober-/ for 2 words. As a result, the numbers of composites in the novel Siddharta are 268 compound words.

Data from the novel Siddhartaby Hesse (1922) and the translated version by Holzwarth (2007) are described as follow.

\section{Data 1:}

..., in der Sonne des Flußufers Booten, im Schatten des Salwaldes, im Schatten des Feigenbaumes wuchs Siddhartha auf, der schöne Brahmanen, der jungeFalke, zusammenmitseinemFreunde, demBrahmanensohn (Hesse, 1922: 1).

'..., disinari matahari pada tebing sungai di dekat perahu-perahu, dalam naungan hutan kayu sal, di bawah bayangan pohon ara, di sanalah Siddhartha tumbuh dewasa, putra tampam sang Brahmana, elang belia, bersama sahabatnya, putra seorang Brahmana' (Holzwarth, 2007: 7).

'..., illuminated by the sun on the riverbank close to the boats, in the shade of sal wood forest, under the shadow of the fig tree was where Siddharta grew up, the handsome son of the Brahma, the young eagle, along with his best friend Govinda, a son of Brahman (Holzwarth, 2007: 7).

Based on data (1), it can be stated that the compound words were derived from the noun Feigen 'figs' and noun Baum 'tree' so that they became the composite Feigenbaum. This composite form did not create konfixappearances in compound words. This was caused by the noun form of Feigen which already has a suffix /-en-/ combined with the noun Baum. Thus, konfixwas not needed anymore since the basic element in the noun which serves as the attribute in the compound word had suffix /-en/. In contrast to thecomposite Brahmanensohn, the attributive noun in the form of noun Brahmanewascombined with the noun Sohn which brought out the konfix /-n-/ to become Brahmanensohn. It deals with the soundpattern.

Composite formation, according to Duden (2005: 712), is known as Kompositionsfuge, that is additional composition in the form of Konfixbeteiligung (vocal or consonant konfixin a compound word). This can be konfix/-s-/, /-s-/, /-es/, /-n-/, /-en-/, and /-er-/ as in the following data.

\section{Data 2:}

In data (2) composites were formed based on the addition of konfix/-s-/ as follows.

..., war nichtmehrsinnlose und zufälligeVielfalt der Erscheinungswelt, ... (Hesse, 1922: 23).

..., bukan lagi keragaman yang sia-sia dan kebetulan dari sekadar penampilan belaka, ... (Holzwarth, 2007: 48).

..., this was no longer a vain diversity and coincidence from mere appearance, ... (Holzwarth, 2007: 48).

Based on data (2), it can be stated that Erscheinungswelt was a composite derived from combined words of Erscheinung (appearance) and Welt (world). German language composite in the word Erscheinungswelt was translated by Holzwarth (2007: 48) as the word penampilan(appearance) in Indonesian. This signified that there was the dissimilarity in the composite construction between German and Indonesian. The German language composite consists of two words, namely the word Erscheinung (appearance) and Welt (dunia), whereas, in Indonesian, there was only one translation to the word, i.e. penampilan. The different construction was caused by the differences in the word or phrases formations in the language. However, the form difference did not differentiate meaning. The equivalent form of it in Indonesian was in the form of meaning 
equivalence instead of in the lexical construction. The meaning equivalent of Erscheinungswelt was penampilan. The form of construction of Erscheinungswelthadinfix /-s-/ which was located in between words in Erscheinungswelt, namely the word Erscheinung+/-s-/+Welt.

The German language composites and the equivalent form are shown in the following data.

\section{Data 3:}

Freude sprang in seines Vaters Herzenüber den Sohn, den Gelehrigen, den Wissensdurstigen, ... (Hesse, 1922: 1).

Kebahagiaan meliputi hati ayahnya melihatputra yang belajardengancepat, selalu haus pengetahuan, ... (Holzwarth, 2007: 8).

Happiness embraced his father who witnessed his fast-learning son, always thirsty for knowledge, ... (Holzwarth, 2007: 8).

Data (3) was a composite Wissensdurstigen (thirst for knowledge) which combined from the noun Wissen + konfix/-s-l + adjective durstig. The combination resulted in a new form called the substantive or new nouns requiring konfix and suffix. Konfix/-s-/ was required to coordinate composites derived from nouns and adjectives. The suffix /-en/ was the plural form of the composite. Similar data are described as follow.

\section{Data 4:}

..., mit der leuchtendenStirn, mitdemKönigsauge, mit den schmalenHüften, ... (Hesse, 1922: 1). ..., dengan dahi bersinar, mata seorang raja, dan pinggul ramping (Holzwarth, 2007: 8).

..., with shining temple, eyes of a king, and slender hip (Holzwarth, 2007: 8).
In data (4), the composite Königsauge (eyes of a king) was a form of new composites formation derived from the noun König(king) + konfix /-s-/ + noun Auge (eyes). Consequently, both nouns became a new meaningful composite meaning mataseorang raja(eyes of a king). Meanwhile, if observed carefully, there were two forms of language composites in both data, namely the composite Wissensdurstigen(thirstyfor knowledge) and Königsauge(eyes of a king). Composite Wissensdurstigen(thirsty for knowledge) consisted of the noun Wissen (knowledge) + konfix /-s-/ + adjective durstig(thirsty), whereas the composite Königsauge(eyes of a king) consisted of a noun König (king)+ konfix/-s-/+noun Auge (eyes). Based on both forms, there were two composite forms derived from noun+adjective and noun+noun.

\section{Data 5}

In data (5), composites were formed based on the addition of konfix /-n-/ as follow.

..., saß auf roten Kissenuntereinembunten Sonnendach eine Frau, die Herrin (Hesse, 1922: 28).

'..., duduk seorang wanita, sang majikan, di bantal-bantal merah di bawah langitlangit beraneka warna' (Holzwarth, 2007: 62).

'..., there sat a woman, the mistress, on the red cushions under the multicolored ceiling' (Holzwarth, 2007: 62).

Based on data (5), there was the structure Sonnendach (ceiling). The word Sonnendach had the structure of Sonne+/$n-/+$ Dach. Accordingly, the addition of konfix/-n-/ which was in between the word Sonnendach, was the German language structure which was equivalent to konfix /-s-/. The konfix functioned as form alignment which had no meaning. However, without konfix/-n-/ in the word 
Sonnendach, the word would not have any meaning. For that reason, the structure of Sonne+/-n-/+Dachwas one unified form which has meanings. The konfix/-n-/ existence was absolutely needed.

\section{Data 6:}

In data (6), the composite was formed by adding konfix/-en-/ as follows.

Zuweilenabererhobersich, trat an die Hüttentür und lauschte, ob der Knabeschlafe (Hesse, 1922: 66).

'Tetapi sesekali ia bangun, melangkah ke pintu gubuk dan mendengarkan, apakah si anak masih tidur' (Holzwarth, 2007: 128).

'But he got up once in a while, stepping to the hut door and listened, whether or not his son was asleep' (Holzwarth, 2007: 128).

Based on data (6), the structure Hüttentürhad a primary form of Hütt+/en-/+Tür. As a result, the word Hüttentür consists of three words, namely the root Hütt (hut), konfix/-en-/, and Tür (door). Those three elements became one word Hüttentür which was equivalent to the Indonesian pintugubuk. Both composites in German and Indonesian have more than one element. Both of them have phrase forms. Still, there are some differences between the two. German language composites have three words, while Indonesian only have two. The word Hüttentür has pintugubuk (hut door)as its equivalent form. The form difference was caused by forms of konfixwhich do not exist in Indonesian. Meanwhile, in German, konfix always become reference in composites formation.

\section{Data 7:}

In data (7), composites were formed based on the addition of konfix/-er-/ as follow.

..., immernochwaren die Menschen der Welt, die Kindermenschen, ihmfremdgeblieben, wieerihnenfremd war (Hesse, 1922: 42).

'..., masih juga orang-orang dunia ini, orang-orang kekanak-kanakan, tetap asing bagi dirinya juga asing bagi mereka' (Holzwarth, 2007: 86).

'...., still the people of this world, the childish ones, remain bizzare for both of him and them' (Holzwarth, 2007: 86).

Based on data (7), the composite structure of Kindermenschenhad the primary form of Kind + konfix /-er-/+the word Menschen. The word Kind (child) and Menschen (persons, people). The composites Kindermenschenwas equal to orang kekanak-kanakan(childish people) in meaning. Both composites had the same form, i.e. in the form of phrases, as well as same meanings. The only difference was that the German language has konfix/er-/, while Indonesian only has phrases without konfix. Thus, it can be said that composites in German and Indonesian have different constructions as in German, these are in the forms of words, whereas in Indonesian, these are in the forms of phrases. On the other hand, both have equivalence in meanings.

Based on the research findings, it is found that there were composites with greatly varied structures. This is all because of the word form variations which became the primary words in the composites. Meanwhile, the structure of the German language composites can be the form of Nullkonfix, i.e. the combination of noun + noun. It was found in 161 composites in the novel Siddharta by Herman Hesse. There were 5 composites as a result of the combination of adjective + noun. There were 22 Konfixbeteiligung /-s-/. It was found as many as 49 Konfixbeteiligung /-n-/ in the novel. There were 6 Konfixbeteiligung /-en-/. The structure of composites in the form of Konfixbeteiligung /-er-/ was found as many as 17 composites. There were 5 Konfixbeteiligung /-r/. 
On the other hand, there were compounding forms by adding prefixes before a word, i.e. Präfixbeteiligung /Ge-l, which was found in 1 word, whereas there were 2 Präfixbeteiligung /Ober-/. So, there were 268 composite forms found in the novel Siddharta.

German language composites can be formed in several ways.Duden (2009: 712) states that the formation includes: (1) composites formed by not changing the form and its basic elements, (2) composites without addition, unless in vocal /-e-/ on the first syllable for several composites which are omitted, as in Schulbuch (school book), (3) composites derived by adding consonant /-s-/ as in Tagesreise (daily trip).

Nevertheless, there were variations of composite formation in German. This is all because of the composite construction which requires linguistic form synchronization. Combinations of two or more words can cause a new form which has no synchronization on its vocal and consonant sounds. For that reason, it can be concluded that the German language composite formation can be in the form of combinations of two or more words derived from noun + adjective and noun + noun elements. The formation needs konfix such as /-s-/, /-es/, /-n-/, /-en-/, dan /-er-/ which were located in between the two words.

\section{CONCLUSION}

Based on the discussion, the conclusion can be drawn as follows.

1. There were 5 forms of German language composites in the novel Siddharta, namely konfix/-s-/,/-es/,/-n-/, /-en-/, and /-er-/. Based on the forms, it could be stated that the appearance of various forms of compound word formations in German was caused by differences in the sentence structure formation which functions as an attribute in the composite. On the other hand, there were also composites having no meaning or Nullkonfix. This was resulted from the attributive form of a word and the word was qualified as a compound word in German which did not need any insertion or konfix.

2. There were 268 German language composites in novel Siddharta, which consist of 161 Nullkonfix, i.e. the combined form between noun + noun and 5 combined form of adjective+ noun. There were 22 Konfixbeteiligung/-s/, 49 Konfixbeteiligung/-n/,6 Konfixbeteiligung /-en/, 17 Konfixbeteiligung /-er/, and 5 Konfixbeteiligung/-r/in whichthese were functioning as compound words.

Based on the conclusion, suggestions for German language learners can be made; learners can master German well by mastering German language composites first. This is caused by the complex form in the nouns. Meanwhile, nouns have various forms depending on the genus. Plural noun forms of German have complex varians as in besonderePluralformen.

\section{ACKNOWLEDGEMENT}

This work was supported by Yogyakarta State University research grant of DIPA. This workwould not have beenpossible without the contribution ssuggestion of the Lecturer Applied Linguistic Postgraduate State University of Yogyakarta Prof. Dr. Pratomo Widodo and Lecturer of the German Academic Exchange Service $(D A A D)$ Svenja Völkert, MA.

\section{REFERENCES}

Buscha, Joachim \& Irene Zoch. (2005). Der Infinitiv. ZurTheorie und Praxis des DeutschunterrichtsfiirAusländer. Leipzig: Langenscheidt Verlag Enzyklopädie. ISBN: 3-468-49493-9.

Duden.(2009). Die Grammatik. Unentbehrlich für richtiges Deutsch. Duden Band 4. Mannheim: Dudenverlag. ISBN: 9783-411-04048-3. 
Donalies, E. (2007): Basiswissen. Deutsche Wortbildung. Tubingen: Narr Francke Attempto Verlag GmbH + Co.KG.

Engel, Ulrich. (2001). Deutsche Grammatik. Heidelberg : Julius GroosVerlag. ISBN: 3-87276-600-7.

Eisenberg, Peter. (2004). Grundriâ der deutschen Grammatik. Stuttgart: Verlag J.B. Metzler. ISBN: 5-476-01252-8.

Gaeta, Livio \& Schlucker, Barbara. (2012). Das Deutsche alskompositionsfreudige Sprache. Strukturelle Eigenschaften und systembezogene Aspekte. Berlin, New York: De Gruyter (= Linguistik Impulse \&Tendenzen 46), 1-25.

Gluck, H. (2000). Metzler-LexikonSprache. 2. uberarb. und erw. Aufl.Stuttgart, Weimar: Metzler.

Herold-Langer, Antje; Angelika Port; Silke Peters; Pauline Villentschuk; Stefan Buch; and Sascha Filyuta. (2003). Fugenelementeoder Kompositionsstammformen?Humboldt-Universitat: LehrstuhlfurKorpuslinguistik.

Helmut Glück (Hrsg.). (2010). MetzlerLexikon Sprache. 4. Auflage; Verlag J.B. Metzler, Stuttgart und Weimar. ISBN 3-476-02335-4.

Lohde, M. (2006).Wortbildung des modernen Deutschen. Tubingen: Narr Franke AttemptoVerlag.
Sudaryanto. (2015). Metode dan Aneka Teknik Analisis Bahasa. Pengantar Penelitian Wahana Kebudayaan secara Linguistik. Yogyakarta: Sanata Dharma University Press.

Sudaryanto. (1996). Linguistik. Identitasnya, Cara Penanganan Objeknya, dan Hasil Kajiannya. Yogyakarta: DutaWacana University Press.

Sudaryanto. (1998). Predikat-Objekdalam Bahasa Indonesia, Keselarasan Pola Umum. Jakarta: Djambatan Press.

Vaverkovaì, Iveta. (2012). Possessivkomposita, Ihre Funktion und Bedeutung in der gegenwärtigendeutschen Presse und Internet-Publizistik. Budweis: Sudbohmische Universitat in Budweis, Padagogische Fakultat Germanistik.

Wray, Alison; Trott, Kate; Bloomer, Aileen. (2009). Linguistics: A Practical Guide to Researching Language. Great Britain: Bookcraft Bath. ISBN: 0340 652101 (pb).

Wortbildung: URL:http://www.canoo. net/services/WordformationRules/ Kompositi-ion/N-Comp/Adj+N/A+N . html?MenuId=WordFormation11501. [4.12.2010].

German Composites in Herman Hesse's Novel Siddharta and Their Correspondences in Indonesia 